\title{
Kontaminasi Logam Berat pada Kerang Bulu Anadara inflate Secara Laboratorium
}

\author{
Chrisna Adhi Suryono \\ Jurusan IImu Kelautan, Fakultas Perikanan dan IImu Kelautan, Universitas Diponegoro. \\ JI. Prof. Soedarto, SH. Kampus UNDIP Tembalang, Semarang 50275 \\ Email : chrisna_as@yahoo.com
}

\begin{abstract}
Abstrak
Masuknya logam berat sepeti Pb kedalam tubuh kerang dapat melalui jaringan makananan atau kontak dengan lingkungannya. Penelitian ini bertujuan untuk mengetahui pengaruh akumulasi logam berat $\mathrm{Pb}$ terhadap filtrasi Anadara inflata. Penelitian eksperimen laboratories ini menggunakan 4 konsentrasi $\mathrm{Pb}$ (19 ppm, 18 ppm, 17 ppm dan 16 ppm) sebagai perlakuan dan diulang sebanyak 3 kali. Hasil penelitian menunjukan kesemua perlakuan menunjukan penurunan kemampuan filtrasi setelah kerang bulu terakumulasi logam $\mathrm{Pb}$ setelah berada dalam media 13 jam kedua.
\end{abstract}

Kata kunci : Anadara inflata, bioakumulasi, $\mathrm{Pb}$

\begin{abstract}
The heavy metal $\mathrm{Pb}$ can be contaminated on Anadara inflata tissue through food web system and direct contact. The aim of present study is to understand the effect of $\mathrm{Pb}$ accumulation on A. inflata filtration. The laboratories experiment with 4 different concentrations of $\mathrm{Pb}(19 \mathrm{ppm}, 18 \mathrm{ppm}, 17 \mathrm{ppm}$ and $16 \mathrm{ppm})$ and 3 replication has done. The result show, that all concentration of $\mathrm{Pb}$ gave negative impact on cockle filtration after the second of 13 hours exposure.
\end{abstract}

Keyword : Anadara inflata, bioaccumulation, $\mathrm{Pb}$

\section{PENDAHULUAN}

Seperti telah di ketahui bahwa kerang bulu A. inflata mendapatkan makanannya dengan menyaring makanan yang berupa mikroalga, bahan organik dan partikel lain dari perairan. Namun akhir akhir ini kondisi perairan pesisir semakin tidak sehat dengan semakin banyaknya buangan ke dalam perairan yang mengandung logam berat seperti $\mathrm{Pb}$. Logam berat yang terakumulasi oleh kerang pada umumnya berasal dari air, sedimen, padatan tersuspensi dan fitoplankton (King dan Davis, 1987). Unsur tersebut masuk kedalam tubuh organisme melalui rantai makanan, insang dan difusi oleh permukaan kulit (Hutagalung, 1991). Lebih lanjut Clark (1994) menginformasikan bahwa logam berat masuk kedalam tubuh melalui makanan, penumpukan senyawa logam dan koloid logam melalui sistim pengumpul makanan seperti insang pada bivalvia.

Kondisi ini tentunya sangat berpengaruh bagi mikroalgae dan kerang bulu sendiri. Mikroalgae jenis diatomae mampu mengakumulasi logam berat dalam selnya demikian juga dengan kerang bulu merupakan bioakumulan bagi logam berat. Tentunya dengan semakin meningkatnya konsentrasi logam berat dalam lingkungan perairan dimana kerang bulu tersebut hidup, akan diikuti dengan meningkatnya akumulasi $\mathrm{Pb}$ dalam kerang bulu A. inflata baik yang masuk melalui rantai makanan dengan perantara diatomae atau secara kontak langsung dengan jaringan insang pada saat penyaringan makanan. Mekanisme 
masuknya logam berat melewati membran sel melalui empat cara, yaitu difusi pasip lewat membran, filtrasi lewat pori pori membran, transport dengan perantaran organ pengangkut dan penyerapan oleh sel (Frank, 1991). Bila akumulasi logam berat tersebut semakin meningkat seiring dengan waktu dan peningkatan konsentrasi logam berat ke perairan maka kerang bulu diduga akan mengalami gangguan dalam melakukan filtrasi makanan, maka kerang tersebut akan mengalami penurunan dalam pertumbuhan dan bahkan dimungkinkan mengalami kematian.

\section{MATERI DAN METODE}

Materi yang digunakan dalam penelitian ini adalah kerang bulu A. inflata yang didapat dari perairan Kedung Jepara, dengan ukuran relatif sama $\pm 2 \mathrm{~cm}$, stok murni mikroalga Skeletonema sebagai pakan yang berasal dari BBAP Jepara dan $\mathrm{Pb}(\mathrm{NO} 3) 2$ dari FMIPA UNDIP. Aklimatisasi dalam laboratorium sebelum penelitian dimulai terhadap $A$. inflata selama 10 hari dan diberi pakan Skeletonema murni, selama aklimatisasi dilakukan pergantian air setiap hari untuk menjaga kuwalitas air (Hasyim, 1986)

\section{Uji Toksisistas Logam Pb}

Uji toksisistas dimaksudkan untuk mengetahui konsentrasi sub lethal logam berat $\mathrm{Pb}$ pada konsentrasi ini selama 96 jam kurang dari 50\% A. inflata mati. Kerang bulu A. inflata didedahkan pada media tercemar logam berat $\mathrm{Pb}$ dan $\mathrm{Cu}$ dengan konsentrasi Kontrol (tanpa penambahan $\mathrm{Pb}), 5 \mathrm{ppm}, 10 \mathrm{ppm}, 15$ ppm dan 20 ppm selama 96 jam dengan kepadatan biota 6 specimen tiap akuarium dengan tiga ulangan. Dari hasil uji LC 50 menunjukan kematian pada konsentrasi 20 ppm Pb kerang bulu mati sebanyak $50 \%$. Jadi dasar konsentrasi yang digunakan dalam perlakuan adalah 20 ppm Pb.

2. Uji Pakan :

Uji pakan dimaksudkan untuk mengetahui waktu yang diperlukan kerang bulu $A$. inflata untuk menghabiskan pakan Skeletonema dengan kepadatan $200.000 \mathrm{sel} / \mathrm{ml}$ (Element et al,. 1977). Bila waktu yang diperlukan oleh $A$. inflata untuk menghabiskan $200.000 \mathrm{sel} / \mathrm{ml}$ adalah B jam, maka waku yang digunakan dalam pengamatan selama penelitian utama dengan konsentrasi logam berat yang berbeda adalah B jam. Dari uji pendahuluan menunjukan bahwa kerang bulu akan menghabiskan Skeletonema sp dengan kepadatan $200.000 \mathrm{sel} / \mathrm{ml}$ adalah $13 \mathrm{jam}$.

Adapun cara perhitungan kecepatan filtrasi menggunakan persamaan (Coughlan, 1969 dalam Suryono dan Suryono, 1997) adalah

\section{$F R=(M / n t) \log e(c o / c t)$}

dimana :

$F R=$ Kecepatan Filtrasi

$M=$ Volume Suspensi

$n=$ Jumlah Hewan Uji

co $=$ Konsentrasi Awal

ct $=$ Konsentrasi akhir

Konsentrasi logam berat yang digunakan dalam penelitian utama ini adalah konsentrasi dibawah sub lethal yang diperoleh dalam penelitian pendahuluan. Misalkan konsentrasi sub lethal adalah $A X=$ 20 ppm maka konsentrasi yang digunakan dalam penelitian utama adalah dibawah konsentrasi sub lethal dengan selisih 1 ppm $(A X-1=19$ ppm, $A X-2=18$ ppm, $A X-3=17$ ppm dan $A X-4=16$ ppm). Untuk selanjutnya Skeletonema sp dengan kepadatan $200 \mathrm{x}$ $10^{6} \mathrm{sel} /$ liter dimasukkan dalam 10 liter akuarium dengan media yang telah ditambahkan $\mathrm{Pb}$ sesuai dengan perlakuan diatas. Diharapkan dengan media yang mengandung $\mathrm{Pb}$ akan terjadi akumulasi $\mathrm{Pb}$ pada Skeletonema sp yang akhirnya termakan oleh kerang bulu sehingga akan terjadi bioakumulasi logam berat dalam kerang bulu melalui jaringan makanan. Dampak dari bioakumulasi Pb pada kerang bulu akan dilihat pada semakin menurunnya kemampuan kerang tersebut dalam menyerap Skeletonema sp.

Ada empat perlakuan konsentrasi logam berat yang berbeda ditambah 1 kontrol dengan 3 ulangan pada tiap 
perlakuan. Penggunaan konsentrasi logam berat $\mathrm{Pb}$ dibawah sub lethal dengan tujuan agar kerang tidak mati pada awal penelitian. Pengamatan kecepatan filtrasi A. inflata terhadap Skeletonema dilakukan setelah 13 jam. Kemudian media diganti dengan media baru dengan konsentrasi logam berat dan jumlah pakan yang sama. Pengukuran kecepatan filtrasi dan pergantian media setiap 13 jam dan penelitan akan berakhir bila dalam penelitian tersebut telah menunjukan adanya kematian pada kerang bulu. Rancangan yang digunakan dalam penelitian ini adalah rancangan acak lengkap dengan perlakuan $\mathrm{Pb}$ (kontrol, 19 ppm, 18 ppm, 17 ppm dan 16 ppm) dengan 3 ulangan. Data yang diperoleh yang berupa kecepatan filtrasi diuji dengan uji One way Anova dengan program Minitab versi 10-2 (Zar, 1996).

\section{HASIL DAN PEMBAHASAN}

Berdasarkan hasil penelitian terhadap laju filtrasi kerang bulu A. inflata terhadap
Skeletonema sp yang dikontaminasikan dengan $\mathrm{Pb}$ pada medianya dengan konsentrasi (19 ppm, 18 ppm, 17 ppm dan 16 ppm) menunjukakn hasil seperti terlihat pada Gambar 1.

Pada gambar 1. terlihat bahwa setelah kerang bulu memfiltrasi Skeletonema sp yang terdapat dalam media yang mengandung $\mathrm{Pb}$ menunjukan penurunan kemampuan memfiltrasi setiap 13 pengukuran. Penurunan tersebut terlihat pada semua perlakuan baik pada media yang mengandung $\mathrm{Pb} 19$ ppm, 18 ppm, 17 ppm maupun 16 ppm. Pada akhir penelitian setelah 13 jam ke 12 terlihat kemampuan memfiltrasi kerang bulu dibawah 0,5 liter/menit. Untuk mengetahui apakah ada perbedaan kecepatan filtrasi akibat $\mathrm{Pb}$ yang masuk kedalam kerang melalui Skeletonema sp dan air maka dilakukan uji anova dengan nilai $(P>0,05)$ yang berarti konsentrasi $\mathrm{Pb} 19 \mathrm{ppm}, 18$ ppm, 17 ppm dan 16 ppm memberi pengaruh yang sama terhadap kecepatan filtrasi (sama nilai penurunannya).

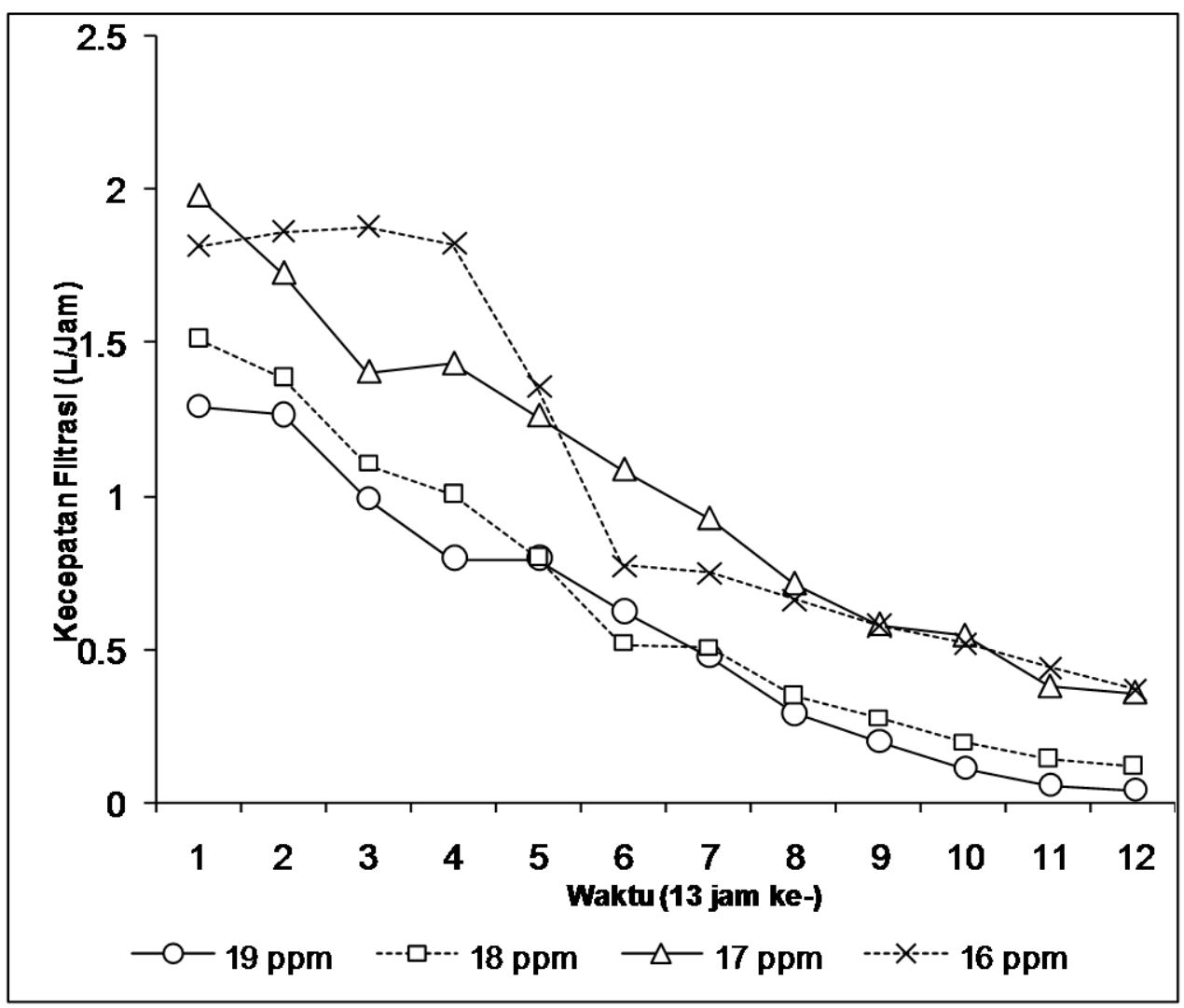

Gambar 1. Grafik penurunan kecepatan filtrasi kerang bulu A. inflata pada media yang tercemar logam berat $\mathrm{Pb}$. 

Untuk mengetahui adanya penyerapan logam berat $\mathrm{Pb}$ yang terdapat pada media masuk ke dalam tubuh kerang bulu, maka pada akhir penelitian dilakukan pengukuran terhadap kandungan $\mathrm{Pb}$ dalam tubuh kerang bulu. Adapun hasil pengukuran menunjukan kerang yang hidup pada konsentrasi $\mathrm{Pb} 19$ ppm, 18 ppm, 17 ppm dan 16 ppm dalam tubuhnya didapatkan $\mathrm{Pb}$ berturut tutut sebagai berikut : 0,0892 ppm, 0,0812 ppm, 0,0765 ppm dan 0,0726 ppm. Sedangkan kandungan $\mathrm{Pb}$ dalam air laut yang digunakan sebagai media sebelum penambahan $\mathrm{Pb}$ adalah 0,0059 ppm.

Hasil penelitian menunjukan bahwa logam berat Pb (19 ppm, 18 ppm, 17 ppm da 16 ppm) memberikan pengaruh yang sama terhadap kemampuan filtrasi kerang bulu yaitu menurunnya kemampuan kerang bulu dalam memfiltrasi. Hal tersebut diduga dikarenakan kerang bulu telah mengakumulasi logam berat $\mathrm{Pb}$ dalam tubuhnya sepeti terlihat dalam hasil analisa ligam berat $\mathrm{Pb}$ dalam tubuh kerang. Penelitian terdahulu seperti yang dilakukan oleh King dan Davis (1987) mengatakan logam berat dapat terakumulasi dalam kerang kerangan berasal dari air, sedimen, dan dari fitoplankton. Lebih lanjut Mandelli (1976) dalam Hutagalung (1991) mengatakan logam berat dapat masuk kedalam tubuh organisme laut dengan cara melalui rantai makanan, insang dan difusi melalui permukaan kulit.

Seperti telah kita ketahui bahwa kerang dalam menyaring makanan dalam air dengan menggunakan insang (Walne, 1978). Akumulasi logam berat oleh kerang dalam insang menyebabkan menurunnya aktivitas respirasi sehingga secara tidak langsung akan berpengaruh terhadap penyerapan makanan. Somero et al, (1977) dalam Sorensen (1991) mengatakan logam berat seperti $\mathrm{Pb}$ dan $\mathrm{Cu}$ akan terakumulasi dalam jaringan insang kerang hijau, yang biasanya akan direspon kerang hijau dengan mengeluarkan lendir yang menyeliputi insang. Hal inilah yang kemungkinan besar berakibat pada penurunan filtrasi kerang, karena dalam memfiltrasi kerang menggunakan insangnya. Hal tersebut terbukti dalam penelitian setelah beberapa lama kerang mengalami penurunan dalam kemampuan filtrasi. Hutagalung dan Razak (1981) juga menginformasikan bahwa semakin tinggi konsentrasi logam berat maka semakin tinggi pula penyerapan dan peningkatan logam berat tersebut oleh kerang dalam jaringan tubuh seperti insang, mantel, gonad, usus dan lambung. Dengan demikian penurunan filtrasi kerang bulu yang terpaparkan logam berat diduga disebabkan oleh adanya gangguan aktifitas kerja sistim organ organ tersebut.

Kerang mempunyai kemampuan mengakumulasikan logam berat dalam tubuhnya maka kandungan logam berat dalam tubuh kerang akan meningkat terus bersamaan dengan lamanya kerang tersebut tinggal dalam perairan yang mengandung logam berat. Bahkan kandungan logam berat dalam tubuh kerang dapat lebih tinggi dibandingkan dengan dengan kandungan di lingkungannya (Hutagalung dan Razak, 1981). Sebenarnya bivalvia mempunyai kemampuan untuk mendetoksifikasi logam berat dengan mensintesis metallothionein. Sepanjang akumulasi logam berat tersebut bersesuaian dengansintesis metallothinein maka kerang dapat terus bertahan hidup. Ketika akumulasi logam berat dalam tubuh kerang meningkat sintesis metallothinein mungkin akan mencapai tingkat maksimum (Simkiss dan Mason, 1983). Hal inilah yang diduga sebagai sebab tetap bertahan hidupnya kerang pada media yang tercemar logam berat.

\section{KESIMPULAN}

Dari hasil penelitian dapat
disimpulkan bahwa kerang dapat mengakumulasi logam berat yang terdapat dalam linkungannya melalui makanan dan filtrasi hal ini terbukti dengan semakin menurunnya kemampuan filtrasi dan meningkatnya kandungan $\mathrm{Pb}$ dalam tubuh kerang bulu A. inflata. 
DAFTAR PUSTAKA

Clrak, R. B. 1994. Marine Pollution. Oxford Science Publications. Oxford.

Darmono, 1995. Logam dalam sistim biologi makluk hidup, UI Press.

Hasyim, M. 1986. Pertumbuhan kerang darah (Anadara granosa) Famili Archidae pada berbagai salinitas serta pemijahan dengan rangsang buatan. UI Press. Jakarta.

Hutagalung, H. P dan Razak, H. 1981. Kandungan logam berat dalam beberapa perairan laut Indonesia, dalam Kondisi lingkungan pesisir dan laut Indonesia. Puslitbang Oceanologi LIPI Jakarta.

Hutagalung, H. P. 1991. Pencemaran laut oleh logam berat dalam beberapa perairan Indonsia. Puslitbang. Oceanologi LIPI. Jakarta.
King and Davis. 1987. Laboratory and field studies of the accumulation of mercury by the mussel Mytilus edulis. Mar Pol Bull, 13(1) : 27 - 29.

Roberts, D. 1976. Mussel and pollution in Marine mussel: Their ecology and physiologi. Cambride University Press. Cambride.

Sorensen, E. M. 1991. Metal poisoning in fish, CRC Press, New York, 95 - 109 pp.

Suryono dan Suryono, C. A. 1997. Laju filtrasi kerang hijau Perna viridis terhadap mikro alga Chaetocheros. Imu Kelautan. Vol 2 (5) : 1 - 4.

Walne, P. R. 1979. Culture of bivalve molluscs. The White Priars Press. London.

Zar, J. E. 1996. Biostatistical analysis. Prentice Hall, New Jaersey. $662 \mathrm{p}$. 